\title{
SIX NEW SPECIES OF TETRAPTERYS (MALPIGHIACEAE)
}

\author{
W. R. ANDERSON ${ }^{\dagger} \&$ C. Anderson ${ }^{1}$
}

\begin{abstract}
Six new species of the Neotropical genus Tetrapterys (Malpighiaceae) are described and illustrated: T. amazonica C.E.Anderson (Brazil, Colombia and Peru), T. andersonii C.E.Anderson (Mexico), T. callejasii W.R.Anderson (Colombia), T. molinae W.R.Anderson (Honduras), T. rzedowskii W.R.Anderson (Mexico) and T. steyermarkii W.R.Anderson (Colombia and Venezuela). All have 4(-6)-flowered umbels as the ultimate inflorescence units, glabrous yellow petals, and samaras with a small dorsal wing in addition to the four large lateral wings.
\end{abstract}

Keywords. Honduras, Malpighiaceae, Mexico, South America, Tetrapterys.

\section{INTRODUCTION}

The large and diverse Neotropical genus Tetrapterys Cav. is named for its samaras with four lateral wings. The flowers, with yellow or pink petals, are borne in umbels, corymbs or pseudoracemes, these often grouped in paniculate inflorescences. Small, interpetiolate stipules are usually present, either free or connate. The six species here newly described were discerned by the late William R. Anderson while working on Tetrapterys as part of a review of Malpighiaceae of Mexico and Central America, and in preparation for the recently published Catálogo de Plantas y Líquenes de Colombia (Anderson \& Anderson, 2016). He left detailed notes for four of these: Tetrapterys callejasii (Colombia), T. molinae (Honduras), T. rzedowskii (Mexico) and T. steyermarkii (Colombia and Venezuela). For the other two, he only noted that they were undescribed: Tetrapterys amazonica (Brazil, Colombia and Peru) and $T$. andersonii (Mexico). Recent molecular work (e.g. Davis \& Anderson, 2010) confirmed W. R. Anderson's long-held opinion that Tetrapterys as traditionally circumscribed is polyphyletic. The novelties presented here have 4(-6)-flowered umbels as the ultimate inflorescence units and glabrous yellow petals; they fall within Tetrapterys subg. Tetrapterys, as delimited by Niedenzu (1928).

\footnotetext{
${ }^{1}$ University of Michigan Herbarium, 3600 Varsity Drive, Ann Arbor, MI 48108, USA. E-mail: chra@umich.edu

$\dagger$ Deceased.
} 


\section{SPECIES Descriptions}

\section{Mexico}

\section{Tetrapterys andersonii C.E.Anderson, sp. nov.}

Tetrapterys andersonii differs from T. schiedeana Schltdl. \& Cham. in its velutinous-tomentose vesture, shorter petioles and larger stipules; from T. molinae W.R.Anderson and T. argentae Bertol. in its free stipules and its smaller, oblong, sagittate petals. - Type: Mexico, Chiapas: slope 5 miles $\mathrm{S}$ of Bochil along the road to Tuxtla Gutiérrez, 4500 ft, 8 viii 1967 (fl), Clarke 120 (holo NY; iso DS). Fig. 1.

Woody vine. Stems very densely velutinous-tomentose, the vesture eventually abraded. Laminas of larger leaves $4.5-7.5 \times 1.8-3.2 \mathrm{~cm}$, narrowly elliptical, apex acute and mucronulate to short-acuminate, base acute, adaxially tomentulose-sericeous but soon glabrous, abaxially tomentose, in age glabrescent, marginal glands (2-)3-5 in the proximal 1/4-1/3(-1/2) along each side, each gland $0.4-0.5 \mathrm{~mm}$ long; petiole 2.5-5 $\mathrm{mm}$ long, tomentose, eglandular; stipules free, $0.5-0.8 \mathrm{~mm}$ long, triangular, glabrous, usually hidden by the dense stem vesture. Inflorescence terminating in umbels of 4 (or 5) flowers, borne singly or in short panicles, tomentose; inflorescence bracts 5-14 mm long, 2.6-9 mm wide, broadly elliptical to ovate, with 1 or 2 prominent to stipitate glands per side on the margin near the base, deciduous in fruit; floriferous bracts $1.2-1.6 \times 0.6-1 \mathrm{~mm}$, narrowly triangular; peduncle $(2.5-) 3-6 \mathrm{~mm}$ long, tomentose; bracteoles 1-1.4 × 0.6-1 mm, oblong, inserted at apex of peduncle; pedicel 3-4 mm long, tomentose. Sepals 1.5-1.7 mm long beyond glands, 1.7-2 mm wide, apex rounded and ciliate, adaxially sericeous in distal $1 / 2$, abaxially glabrous but with hairs between glands, the anterior eglandular, the lateral 4 biglandular, glands $2.5-3 \mathrm{~mm}$ long. Petals yellow, drying red, the lateral 4 with the claw $1.8-2 \times$ c.0.5 mm, limb $4.5-5.5 \times$ 3.5-4 mm, narrowly oblong to obovate, base sagittate, margin minutely denticulate to erose; posterior petal with the claw $2.5-3 \times$ c. $0.8 \mathrm{~mm}$, limb 5-5.5 $\times 3.5-4 \mathrm{~mm}$, oblong to narrowly obovate, truncate to briefly sagittate, margin minutely erose or erose-denticulate. Filaments $2.3-3.3 \mathrm{~mm}$ long, glabrous, connate in proximal 1/4(-1/2); anthers $1.2-1.3 \mathrm{~mm}$ long, subequal, glabrous. Ovary c. $2 \mathrm{~mm}$ long, hirsute; styles 2-2.3 $\mathrm{mm}$ long, the anterior slightly longer and more slender than the posterior 2, glabrous, all with apex dorsally rounded or truncate and stigma at internal angle. Samara with the wings sericeous-tomentulose to glabrescent; lateral wings distinct and usually tapering towards an acute apex, 15-20 × 5-7 mm; dorsal wing 3-4 mm high, margin subentire; nut 4.5-5 mm diam., tomentose, between dorsal and lateral wings muricate and with a few outgrowths to $0.1 \mathrm{~mm}$ long but hidden by the dense vesture; areole $1.5-2 \times$ c. $1.5 \mathrm{~mm}$; mature seed not seen.

\section{Distribution. Mexico (Chiapas).}

Habitat. Lower montane rain forests, oak and pine-oak forests, and brush; 600$1450 \mathrm{~m}$. 


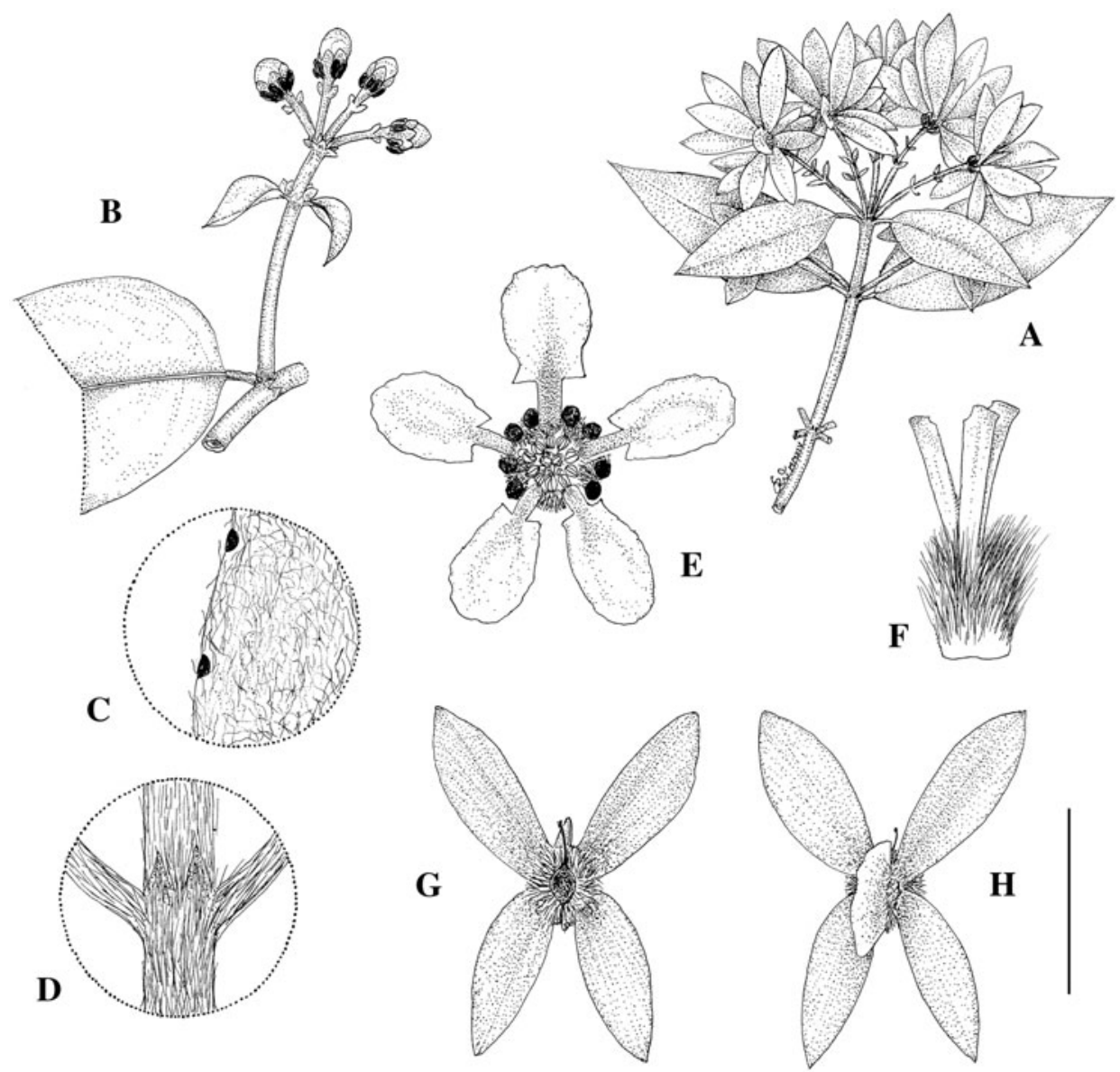

FIG. 1. Tetrapterys andersonii C.E.Anderson. A, Fruiting branch; B, node with portion of leaf and inflorescence in bud; $\mathrm{C}$, detail showing abaxial vesture of lamina and marginal glands; $\mathrm{D}$, detail of node showing a pair of stipules; E, flower, posterior petal uppermost; F, gynoecium, anterior style at left; $G$, samara, adaxial view; $H$, samara, abaxial view. Scale bars: A, $4 \mathrm{~cm}$; B, 2 $\mathrm{cm}$; $\mathrm{C}$ and D, $4 \mathrm{~mm}$; E, $8 \mathrm{~mm}$; F, $2.7 \mathrm{~mm}$; $\mathrm{G}$ and H, $1.3 \mathrm{~cm}$. A, D, G and $\mathrm{H}$ based on Anderson \& Laskowski 4255 (MICH); B and C on Breedlove 10662 (DS); and E and F on Clarke 120 (DS).

Etymology. The specific epithet commemorates William Russell Anderson (19422013), who devoted his career to the study of the Malpighiaceae.

Additional specimens examined. Mexico. Chiapas: $21 \mathrm{mi} \mathrm{N}$ of Mex hwy 195, road to Pichucalco, 1450 m, 19 xi 1966 (fr), Anderson \& Laskowski 4255 (ENCB, MICH); Mpio. Tuxtla Gutiérrez, steep slope at El Sumidero, $22 \mathrm{~km}$ N of Tuxtla Gutiérrez, 4500 ft, 2 vii 1965 (fl), Breedlove 10662 (DS); Mpio. Ocozocoautla de Espinosa, $32 \mathrm{~km} \mathrm{NW}$ of Ocozocoautla de Espinosa, $600 \mathrm{~m}, 27$ viii 1972 (in bud), Breedlove 27497 (DS, MICH).

Tetrapterys andersonii is distinctive in the white-tomentose vesture that covers the young stems, axes, petioles and abaxial surface of laminas. It is reminiscent of 
Tetrapterys argentea Bertol. and T. molinae W.R.Anderson, but these have connate stipules; see detailed notes below under T. molinae. Tetrapterys andersonii and $T$. schiedeana Schltdl. \& Cham., which occurs from southern Mexico to Costa Rica and adjacent Panama, are sympatric in Chiapas. Both differ from members of the Tetrapterys mexicana Hook. \& Arn. complex in their smaller oblong petals, which are generally sagittate at the base and turn orange to red in age and on drying. They share leaf glands borne on the margin of the lamina and free stipules, but are easily separated by leaf vesture.

a. Leaves tomentose, abaxially glabrescent only in age; petioles $2.5-5 \mathrm{~mm}$ long, tomentose; stipules $0.5-0.8 \mathrm{~mm}$ long; lateral wings of samara mostly tapered towards an acute apex T. andersonii

b. Leaves with sessile to subsessile hairs only when very young, soon glabrescent to glabrous or with scattered hairs remaining on costa abaxially; petioles 4-10(-12) $\mathrm{mm}$ long, sericeous to glabrescent; stipules minute, to $0.3 \mathrm{~mm}$ long; lateral wings of samara rounded at apex

T. schiedeana

Tetrapterys rzedowskii W.R.Anderson, sp. nov.

Tetrapterys rzedowskii differs from T. schiedeana Schltdl. \& Cham. in its larger petals with a suborbicular limb remaining yellow in age and in the posterior petal differing from the lateral ones, from T. heterophylla (Griseb.) W.R.Anderson in having the bracteoles inserted at the apex of the peduncle and the absence of distinctive inflorescence bracts. - Type: Mexico, San Luis Potosí: Tamasopo Canyon, 6 viii 1890 (fl/fr), Pringle 3636 (holo MEXU; iso A, GH, MEXU, VT). Fig. 2.

Vining shrub to $2-3 \mathrm{~m}$. Stems sericeous when young, soon glabrate to glabrous. Laminas of larger leaves 6-11.5 × 2.5-5.3 cm, elliptical, apex acuminate, base acute, initially sericeous, adaxially soon glabrous, abaxially soon sparsely and often patchily sericeous to glabrate or eventually glabrous, the hairs straight, appressed, marginal glands $3-7$ in the proximal $1 / 4-1 / 2$ along each side, each gland $0.2-0.4 \mathrm{~mm}$ long; petiole $0.6-1.5 \mathrm{~cm}$ long, sericeous to glabrescent, eglandular; stipules free, $0.3-0.6 \times$ 0.3-0.5 mm, triangular, glabrous. Inflorescence terminating in umbels of 4-6 flowers, borne singly or in short panicles, sparsely sericeous to glabrate; inflorescence bracts absent or sometimes reduced leaves present; floriferous bracts $1-1.1 \mathrm{~mm}$ long, ovate to oblong; peduncle (2.5-)4.5-7.5 mm long, sericeous; bracteoles 0.6-1 mm long, ovate to oblong, inserted at apex of peduncle; pedicel 4.5-7 mm long, sericeous. Sepals (1.2-) $1.5-2 \mathrm{~mm}$ long beyond glands, $1.5-2 \mathrm{~mm}$ wide, apex broadly rounded and ciliate, adaxially glabrous, abaxially sparsely sericeous to glabrous, the anterior eglandular, the lateral 4 biglandular, glands $1.8-2.6 \mathrm{~mm}$ long. Petals yellow, the lateral 4 with the claw c. $1.5 \times$ c. $0.5 \mathrm{~mm}$, limb (4.5-)5-6 mm long and wide, orbicular, base cuneate to rounded, margin minutely denticulate to erose; posterior petal with the claw 3 $3.2 \times$ c. $1 \mathrm{~mm}, \operatorname{limb} 4-5 \mathrm{~mm}$ long and wide, ovate to suborbicular, base truncate to slightly cordate, margin minutely erose or erose-denticulate. Filaments $1.5-2.5 \mathrm{~mm}$ long, glabrous, connate at base; anthers 1-1.4 mm long, subequal, glabrous. Ovary 


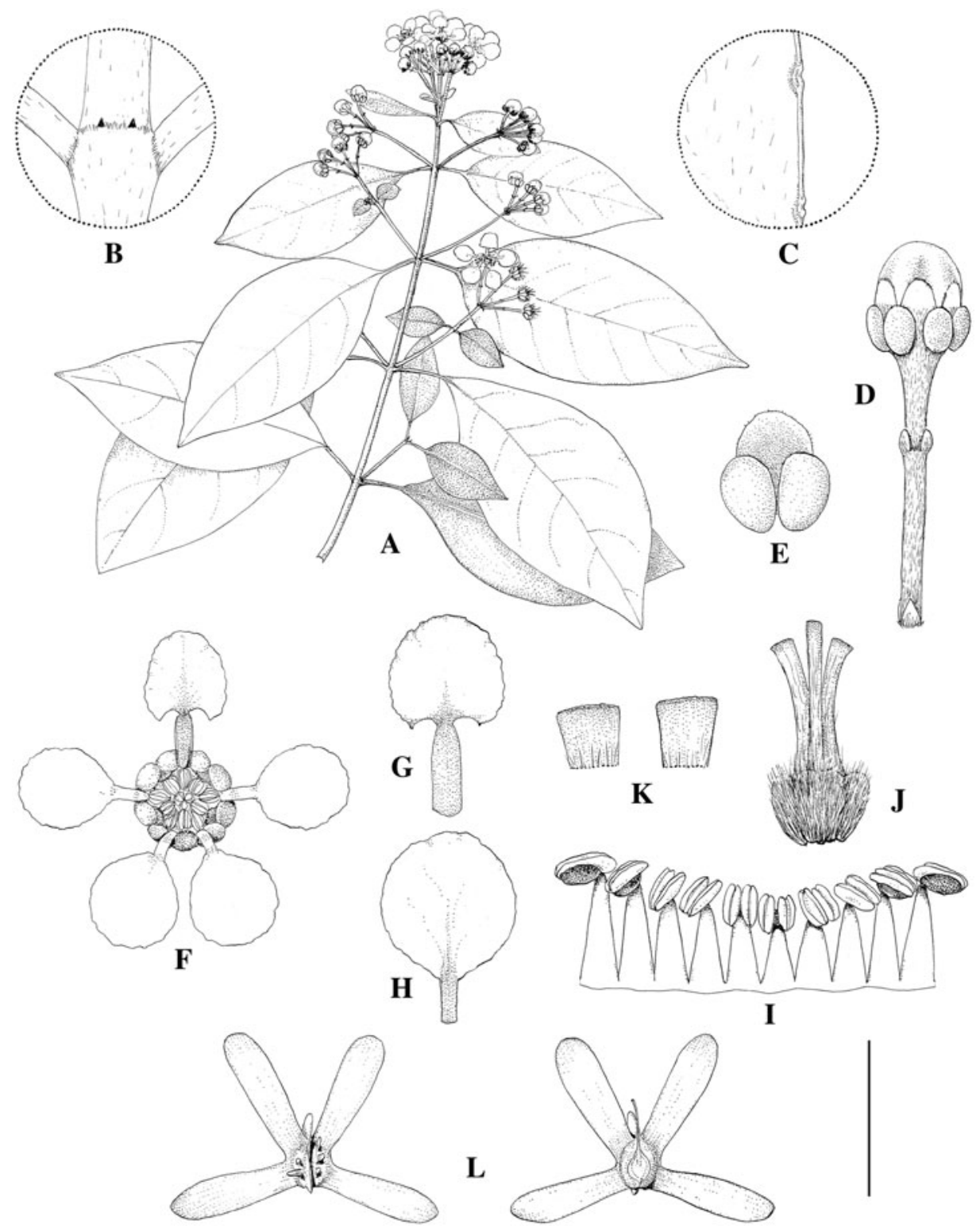

FIG. 2. Tetrapterys rzedowskii W.R.Anderson. A, Flowering branch; B, node with interpetiolar stipules; $\mathrm{C}$, glands on leaf margin, abaxial view; D, flower bud on pedicel subtended by peduncle with bracteoles at apex and floriferous bract at base; E, sepal, abaxial view; F, flower, posterior petal uppermost; G, posterior petal; H, lateral petal; I, androecium laid out, abaxial view with anthers reflexed, the stamen fifth from right opposite posterior petal; J, gynoecium, anterior style in centre; $\mathrm{K}$, distal portions of styles, lateral (left) and anterior (right); L, samaras, abaxial view (left) and adaxial view (right). Scale bars: A, $4 \mathrm{~cm}$; B and C, $4 \mathrm{~mm}$; D, $5.7 \mathrm{~mm}$; E, $4 \mathrm{~mm}$; F, $8 \mathrm{~mm}$; G and H, $5.7 \mathrm{~mm}$; I and J, $2.7 \mathrm{~mm}$; K, $1 \mathrm{~mm}$; L, $2 \mathrm{~cm}$. A-K based on Rubio 716, MICH; and L on Loredo M. 24, MICH. 
c. $1.5 \mathrm{~mm}$ long, hirsute, styles $2.4-2.6 \mathrm{~mm}$ long, with scattered hairs, the anterior slightly longer and more slender than the posterior 2, stigmas terminal. Samara with the wings glabrate; lateral wings distinct, apex rounded, the upper 13.5-15 $\times 6-7 \mathrm{~mm}$, the lower $12.5-15 \times 4.5-6 \mathrm{~mm}$; dorsal wing $3.5-5 \mathrm{~mm}$ high, margin coarsely dentate; nut c.5.5 mm diam., sparsely sericeous, between dorsal and lateral wings muricate, often also with a few outgrowths and/or winglets; areole $2.5-3 \times$ c. $2 \mathrm{~mm}$; embryo spherical.

Distribution. Mexico (Hidalgo, Querétaro and San Luis Potosí).

Habitat. Oak, oak-Liquidambar and pine-oak forests; 800-1250 m.

Etymology. The species is named in honour of the eminent botanist Jerzy Rzedowski (b. 1926), in recognition of his invaluable contributions to Mexican botany, as scholar and collector, educator, editor and administrator, and in gratitude for his kindness and generosity.

Additional specimens examined. Mexico. Hidalgo: Mpio. Chapulhuacán, Puerto Obscuro, 20 ix 1964 (fr), González Q. 1636 (DS, ENCB). Querétaro: Mpio. Pinal de Amoles, La Cuesta, 3 km al S de Escanelilla, 8 vi 1983 (fl), Fernández N. 1577 (MICH), 15 vii 1983 (fr), Fernández N. 1650 (MICH); Mpio. Jalpan, c. 4 km al N de La Parada, 21 vi 1989 (fl), Loredo M. 23 (MICH); Mpio. Jalpan, c. 7 km al N de La Parada, 2 vi 1989 (fl), Loredo M. 24 (MICH); Mpio. Landa, $1.5 \mathrm{~km}$ al SE de El Naranjo, 22 v 1989 (fl/y fr), Rubio 716 (MICH); Mpio. Landa, $25 \mathrm{~km}$ al NW de Agua Zarca, 29 vii 1989 (fr), Rubio 921 (MICH); Mpio. Landa, $1.5 \mathrm{~km}$ al NW de El Sabanito, 4 viii 1989 (fr), Rubio 940 (MICH); Mpio. Landa, $1.5 \mathrm{~km}$ al SE de Neblinas, 27 vi 1990 (fl), Rubio 1760 (MICH); Mpio. Landa, 2 km al SE de El Rincón, 6 viii 1990 (fl), Rubio 1858 (MICH); Mpio. Landa, $1.5 \mathrm{~km}$ al E de El Sabino, 23 vii 1991 (fl), Rubio 2484 (MICH); Mpio. Landa, Puerto de San Agustín, 10 viii 1991 (fr), Rubio 2533 (MICH); Mpio. Landa, $10 \mathrm{~km}$ al NE de Agua Zarca, sobre el camino a Neblinas, 23 vi 1988 (fr), Rzedowski 46848 (IEB); Mpio. Jalpan, 3-4 km al E de La Parada, 6 vi 1990 (fl/fr), Servín 328 (MICH).

Tetrapterys rzedowskii belongs to the T. mexicana complex, in all of which the limbs of the lateral petals are c. $6 \mathrm{~mm}$ or more long, suborbicular and cuneate or rounded at the base, and yellow even in age or when dried. The posterior petal is strongly differentiated from the lateral four, having a thick red claw and a smaller limb, and the peduncle + pedicel are usually at least $10 \mathrm{~mm}$ long in flower and longer in fruit. Tetrapterys mexicana and $T$. cotoneaster A.Juss. have the sepals abaxially \pm densely hairy, at least proximally, whereas in T. heterophylla (Griseb.) W.R.Anderson and T. rzedowskii the sepals are abaxially glabrous or at most ciliate on the margin. The latter two species can be distinguished with the following couplet.

a. Leaf hairs, if present, straight, strongly appressed, parallel; bracteoles borne at apex of peduncle; inflorescence bracts usually absent from node below umbel, if present resembling miniature petiolate leaves T. rzedowskii

b. Leaf hairs, if present, serpentine or twisted, often \pm raised, not parallel; bracteoles borne well below apex of peduncle; inflorescence bracts borne at node below umbel, short and round, sometimes broader than long, sessile, quite different in shape from vegetative leaves T. heterophylla 


\section{Honduras}

Tetrapterys molinae W.R.Anderson, sp. nov.

Tetrapterys molinae differs from $T$. argentea Bertol. in its persistent white-woolly vesture and its samara with a longer dorsal wing extending into a pronounced basal tooth and with the nut bearing outgrowths and winglets between the lateral and dorsal wings. - Type: Honduras, Intibucá: Los Baños, La Esperanza town, 1700 m, 12 iii 1970 (fl/fr), Molina R. \& Molina 25532 (holo NY; iso BM, F, GH, MO, US). Fig. 3.

Woody vine to $4 \mathrm{~m}$. Stems and axes densely white-woolly, the vesture eventually thinning, and old axes glabrate to glabrous. Laminas of larger leaves 5.5-11.5 $\times 3-$ $6 \mathrm{~cm}$, elliptical, those near inflorescences often obovate, apex apiculate, base acute, adaxially and abaxially densely white-woolly, eventually the vesture thinning and patchily sloughed off, the hairs sinuous or curled and twisted, spreading, marginal glands (2-)3-7 in the proximal 1/4-1/2(-2/3) along each side, each gland $0.4-0.8 \mathrm{~mm}$ long; petiole 1.3-2 cm long, densely white-woolly, eventually glabrescent, eglandular; stipules connate, the smallest at distalmost nodes sometimes free, connate stipules $0.7-$ $1.8 \times 0.7-1.1 \mathrm{~mm}$, triangular or bifid, free stipules $0.2-0.9 \times 0.2-0.4 \mathrm{~mm}$, square to oblong, all glabrous. Inflorescence terminating in umbels of 4 flowers, borne singly or in short panicles, white-woolly; inflorescence bracts $4.5-9(-13) \times 2.5-4(-8) \mathrm{mm}$, elliptical, abaxially with 1-3 marginal glands on each side of costa proximally, deciduous in fruit; floriferous bracts $1-1.5 \mathrm{~mm}$ long, linear to narrowly triangular; peduncle $2.5-5 \mathrm{~mm}$ long, white-woolly; bracteoles $0.6-1.2 \mathrm{~mm}$ long, linear to oblong, inserted at apex of peduncle; pedicel 3.5-6 mm long, white-woolly. Sepals $1.3-1.5 \mathrm{~mm}$ long beyond glands, $1.3-1.5 \mathrm{~mm}$ wide, apex broadly rounded and ciliate, adaxially and abaxially white-woolly, the anterior eglandular, the lateral 4 biglandular, glands $1.6-2.2 \mathrm{~mm}$ long. Petals yellow, drying red, the lateral 4 with the claw $1.5-2 \times$ c. $0.5 \mathrm{~mm}$, limb 5.5-6 mm long and wide, orbicular, base cuneate or briefly truncate, margin minutely erose-denticulate; posterior petal with the claw 3-3.3 $\times$ c. $1 \mathrm{~mm}$, limb 5-6 6 5.5-6 mm, broadly triangular but apex rounded, base truncate to slightly cordate, margin minutely erose-denticulate. Filaments $1.8-2.2 \mathrm{~mm}$ long, glabrous, connate at base but those of stamens opposing the posterior petal and posterior-lateral sepals up to $1 / 2$ united; anthers 1-1.2 mm long, subequal, glabrous. Ovary 1.5-1.6 mm long, hirsute, styles glabrous, anterior style 2-2.5 mm long, stigma at internal angle, posterior styles $1.8-$ $2.3 \mathrm{~mm}$ long, stigmas terminal and decurrent at internal angle. Samara with the wings thinly tomentulose to glabrescent; lateral wings distinct, apex rounded, the upper and lower subequal, 14-22 $\times(4-) 5-6.5(-8) \mathrm{mm}$; dorsal wing 4-8 $\mathrm{mm}$ high, margin irregular-wavy, usually with an elongated tooth at base; nut 4-5.5 $\mathrm{mm}$ diam., whitewoolly, between dorsal and lateral wings muricate and with outgrowths and linear winglets up to $10 \mathrm{~mm}$ long; areole $3-3.5 \times 2-3 \mathrm{~mm}$; mature seed not seen.

Distribution. Honduras (Francisco Morazán, Intibucá, Lempira).

Habitat. Mixed forests, pine-oak forests, and thickets, 1300-2000 m. 


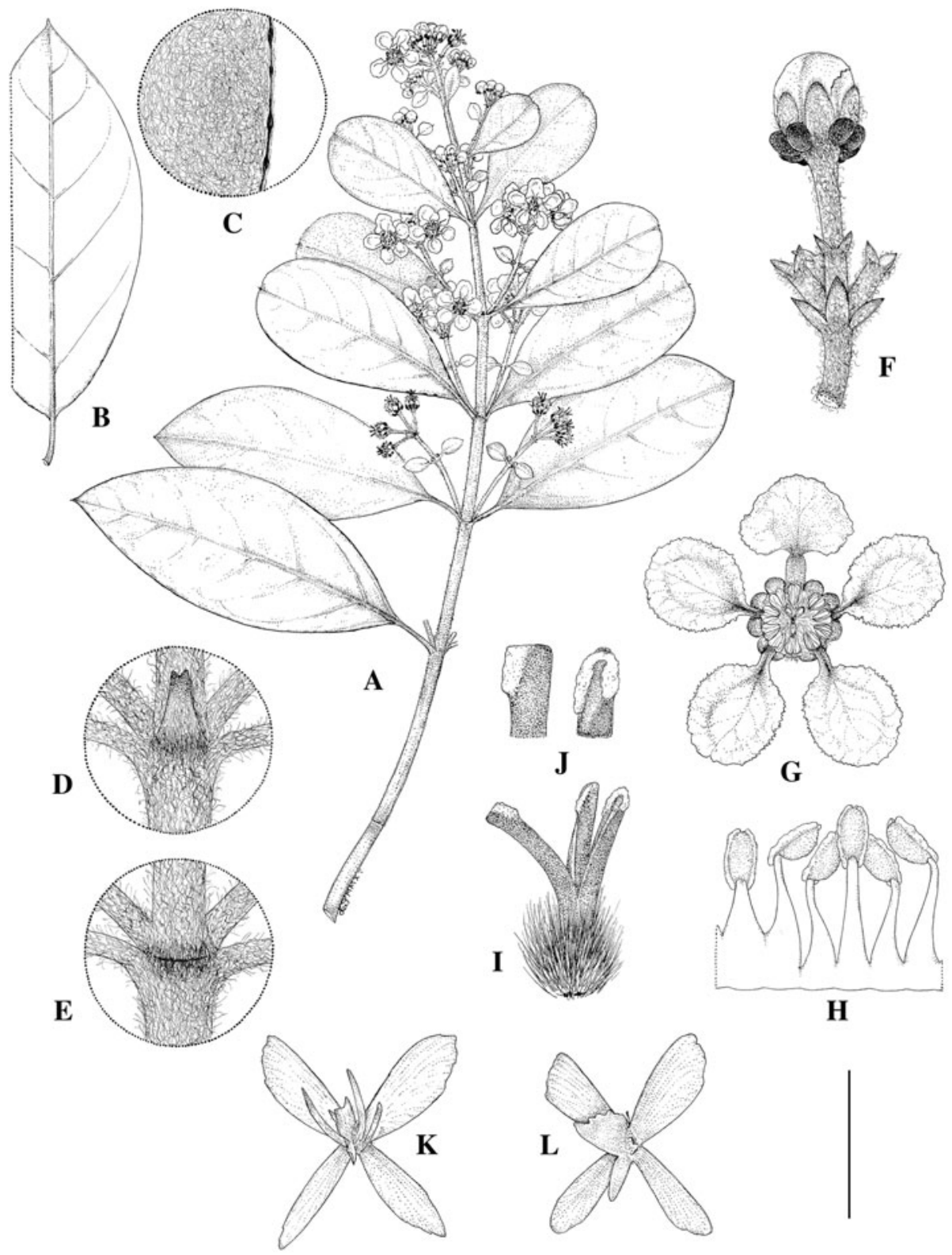

FIG. 3. Tetrapterys molinae W.R.Anderson. A, Flowering branch; B, large leaf, abaxial view; $\mathrm{C}$, abaxial surface of lamina to show vesture and marginal glands; D, node with triangular interpetiolar pair of connate stipules; E, node showing interpetiolar scar after fall of pair of connate stipules; F, flower bud in umbel of four; $\mathrm{G}$, flower, posterior petal uppermost; $\mathrm{H}$, portion of androecium laid out, abaxial view, stamen at left opposite posterior petal; I, gynoecium, lateral view, anterior style at left; $\mathrm{J}$, distal portions of anterior style (left, lateral view) and posterior style (right, adaxial view); $\mathrm{K}$ and $\mathrm{L}$, samaras from different plants, abaxial views. Scale bars: $\mathrm{A}$ and $\mathrm{B}$, $4 \mathrm{~cm}$; C-E, $4 \mathrm{~mm}$; F, $6.7 \mathrm{~mm}$; G, $8 \mathrm{~mm}$; $\mathrm{H}$ and I, $2.7 \mathrm{~mm}$; J, $1.3 \mathrm{~mm}$; K and L, $2 \mathrm{~cm}$. A-J based on Molina 25532, NY; K on Molina 6273, F; and L on Molina 24294, NY. 
Etymology. The specific epithet honours José Antonio Molina Rosito (1926-2012), renowned student and prodigious collector of the Honduran flora.

Additional specimens examined. Honduras. Intibucá: Quebrada Honda, 24 ii 1987 (fl), House 14 (BM, MICH); región entre Las Pilas y camino a Yamaranguila, 6 iv 1956 (fr), Molina R. 6273 (F, GH, US); La Esperanza, 12 i 1969 (fr), Molina R. 23359 (BM, DS, F, GH, NY, WIS); Quebrada Lejarsia, between Km 9-11 on road La Esperanza-Marcala, 21 iii 1969 (fl/fr), Molina R. \& Molina 24294 (BM, F, DS, NY); Cerro San Cristóbal, 2 km al S de La Esperanza, 26 iv 1989 (fr); Peña 180 (F). Francisco Morazán: along Lepaterique river, $5 \mathrm{~km}$ to Lepaterique, $29 \mathrm{v} 1976$ (fr), Molina R. \& Molina 31498 (ENCB, F, MO). Lempira: east slopes of Quebrada Naranja, 10 km SE of Gracias, Celaque National Park, 14³3’ N, 8840’W, 29 i 1992 (fr), Hawkins 146 (MO).

Tetrapterys molinae, known only from Honduras, is readily distinguished by the striking white-woolly vesture that covers all vegetative parts and is only gradually lost with age. Superficially it resembles Tetrapterys argentea of Chiapas (Mexico), Guatemala and El Salvador, in which the young shoots and inflorescence-bearing axes are white-sericeous. The two species may be separated with the following couplet.

a. Lamina originally densely white-woolly, the hairs twisted and spreading, eventually glabrescent, much sooner adaxially than abaxially; stems/axes densely and persistently white-woolly, eventually and gradually glabrescent; dorsal wing of samara 4-8 mm high, usually with an elongated tooth at base, margin sinuous, surface of nut between lateral and dorsal wings bearing numerous outgrowths and winglets

T. molinae

b. Lamina subsericeous to sericeous, the hairs appressed, the vegetative leaves soon glabrate/glabrous, and only the reduced leaves associated with the inflorescence remaining silvery; stems/axes abruptly glabrate to glabrous and only the youngest branches and inflorescence-bearing axes remaining sericeous, such that a sericeous internode is adjacent to a glabrate/glabrous internode; dorsal wing of samara 1.1-1.4 mm high, without a tooth at base, margin grossly dentate, surface of nut between lateral and dorsal wings bearing a single winglet T. argentea

\section{South America}

Tetrapterys amazonica C.E.Anderson, sp. nov.

Tetrapterys amazonica differs from T. crispa A.Juss. and T. discolor (G.Mey.) DC. in its densely golden-sericeous inflorescence, adaxially sericeous stipules, and presence of large basal glands on the abaxial surface of the lamina, from T. crispa also in the presence of winglets and outgrowths on the nut of the samara between the lateral and dorsal wings. - Type: Colombia, Amazonas: Parque Nacional Natural Amacayuna, Centro Administrativo Mata-Matá (Inderena) troche hacia San Martín en tierra alta, $03^{\circ} 47^{\prime} \mathrm{S}, 70^{\circ} 15^{\prime} \mathrm{W}, 135 \mathrm{~m}, 12$ ii 1991 (fl), Rudas \& del Aguila J. 1252 (holo MICH; iso COAH, MO). Fig. 4.

Woody vine to $20 \mathrm{~m}$. Stems densely sericeous when young, soon glabrous. Laminas of larger leaves $8.5-18 \times 3-8 \mathrm{~cm}$, elliptical to broadly so or oblanceolate, apex acuminate, 


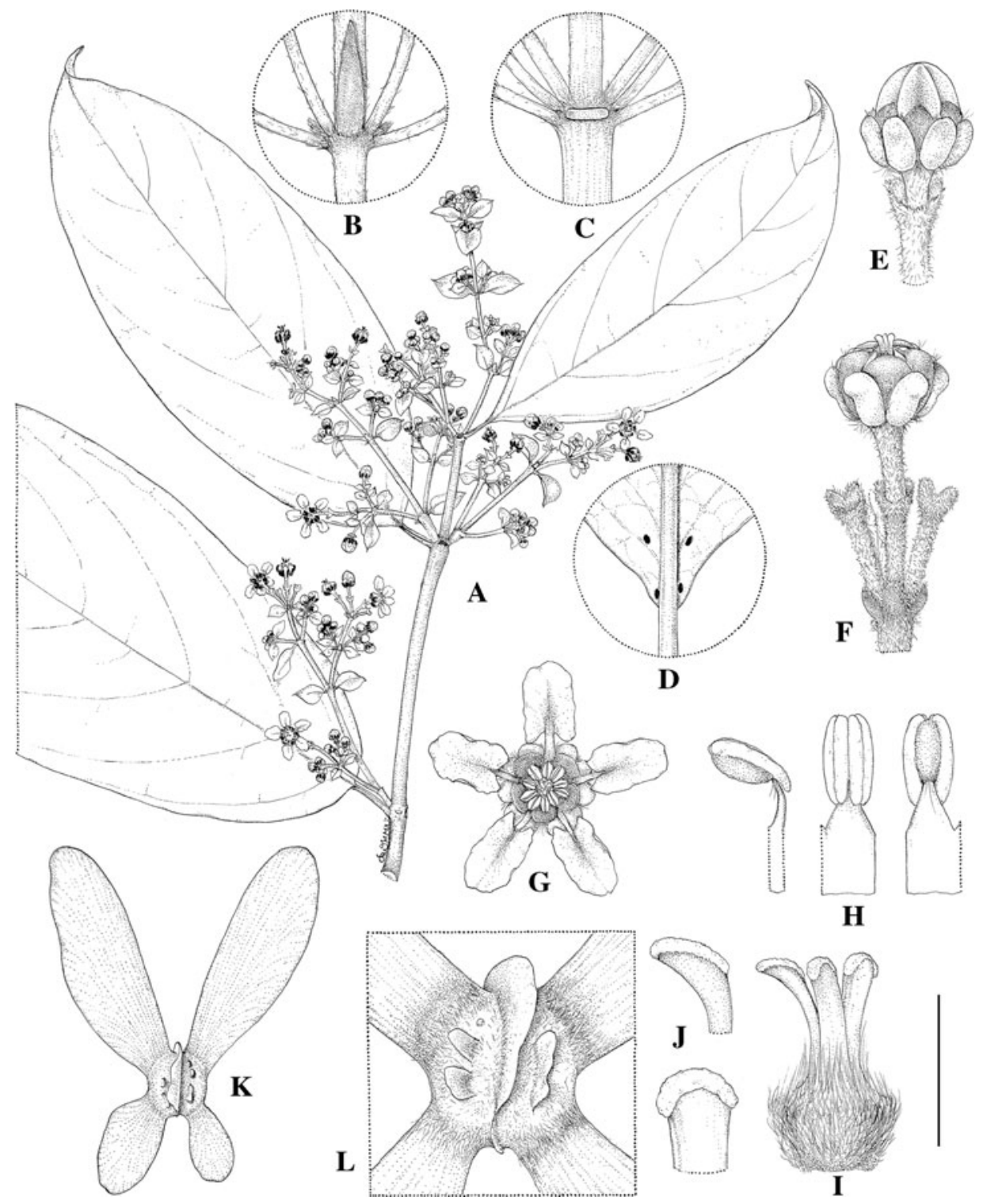

FIG. 4. Tetrapterys amazonica C.E.Anderson. A, Flowering branch; B, node in inflorescence with connate pair of interpetiolar stipules; $\mathrm{C}$, older node with scar from loss of connate pair of interpetiolar stipules; D, glands on abaxial base of lamina; E, flower bud to show keeled petals; F, umbel with three of the four flowers and petals removed; $\mathrm{G}$, flower, posterior petal uppermost; $\mathrm{H}$, stamens, lateral view (left), adaxial view (centre) and abaxial view (right); I, gynoecium, anterior style to left; J, lateral views of distal portions of styles, anterior style (above) and lateral style (below); K, samara, abaxial view; L, enlargement of nut of samara, abaxial view. Scale bars: A, $4 \mathrm{~cm}$; B-D, $8 \mathrm{~mm}$; E, $6.7 \mathrm{~mm}$; F and G, $8 \mathrm{~mm}$; H and I, $2 \mathrm{~mm}$; J, $1.3 \mathrm{~mm}$; K, $2 \mathrm{~cm}$; L, $8 \mathrm{~mm}$. A and $\mathrm{C}-\mathrm{J}$ based on Rudas \& del Aguila 1252, MICH; B on Gentry et al. 29818, MO; and K and L on Prance et al. 12387, NY. 
base acute, adaxially and abaxially initially loosely sericeous but soon glabrous, abaxially on the surface with 1-3 glands on each side of costa widely spaced apart 1-3 $\mathrm{mm}$ from margin, glands $0.2-0.5 \mathrm{~mm}$ diam., also near base with (1 or) 2 larger glands on each side of costa, sometimes lower gland at base of lamina or apex of petiole, glands 0.4-0.7 mm diam; petiole $8.5-10 \mathrm{~mm}$ long, densely sericeous in youngest leaves but soon glabrescent, eglandular; stipules connate, 3-5.2 $\times 1.5-1.8 \mathrm{~mm}$, much shorter at the distalmost inflorescence nodes, narrowly triangular, adaxially in the proximal $1 / 3$ to entirely sericeous, abaxially sparsely sericeous to glabrate. Inflorescence terminating in umbels of 4 flowers, paniculate, golden-sericeous; inflorescence bracts 3.5-17 $\times$ 3-6 $\mathrm{mm}$, the larger elliptical, the smaller ovate, abaxially near base with $(0-) 1(-2)$ gland(s) on each side of costa, deciduous in fruit; floriferous bracts 1.5-2 mm long, ovate; peduncle 3-4.5 mm long, densely golden sericeous; bracteoles $1.2-1.5 \mathrm{~mm}$ long, ovate, inserted at apex of peduncle; pedicel 2.5-5 $\mathrm{mm}$ long, densely golden sericeous. Sepals 1.2-1.5 mm long and wide beyond glands, apex rounded and ciliate, adaxially and abaxially glabrous, the anterior eglandular or rarely glandular, the lateral 4 biglandular, glands $2.7-3.2 \mathrm{~mm}$ long. Petals yellow, posterior and lateral petals subequal, claw 1.5-2 × c.0.4 mm, limb (4-)4.5-5.5 × 3-3.5 mm, oblong, carinate, base briefly sagittate, margin subentire or minutely erose. Filaments $1.6-2 \mathrm{~mm}$ long, glabrous, connate in the proximal 2/3-3/4; anthers c. $1 \mathrm{~mm}$ long, subequal, glabrous. Ovary 1.2-1.5 mm long, hirsute; styles glabrous, anterior style 1.7-2 mm long, stigma terminal and decurrent at internal angle, posterior styles 1.5-1.7 mm long, stigma terminal and slightly decurrent. Samara with the wings sericeous to sparsely so; lateral wings distinct, apex rounded, the upper $2-3.6 \times 0.6-1.2 \mathrm{~cm}$, the lower $1-2.2 \times 0.5-0.7$ $\mathrm{cm}$; dorsal wing 2.5-4.3 $\mathrm{mm}$ high, margin shallowly erose; nut 6-9 $\mathrm{mm}$ diam., sericeous, between dorsal and lateral wings slightly muricate and with outgrowths/winglets; areole $2.5-3.5 \times 2.5-3 \mathrm{~mm}$; mature seed not seen.

Distribution. Brazil (Acre), Colombia (Amazonas), Peru (Amazonas, Loreto, Ucayali).

Habitat. In primary and secondary rain forests, varzea forest; 135-290 m.

Etymology. The specific epithet refers to the Amazonian range of this species.

Additional specimens examined. Brazil. Acre: Mpio. Santa Rosa, Alto Rio Purus, Igarapé

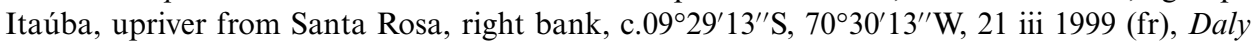
et al. 9905 (MICH); Mpio. Santa Rosa, Rio Chandless (tributary of Rio Purus), right bank, just downstream from Igaparé Canamarí, c. $09^{\circ} 23^{\prime} 0.6^{\prime \prime} \mathrm{S}, 6^{\circ} 57^{\prime} 18.1^{\prime \prime} \mathrm{W}, 29$ iii 1999 (fr), Daly et al. 10181 (MICH); Rio Chandless (tributary of Rio Purus), right bank, "Canamari," c.09²3'0.6" $\mathrm{S}$, 69 56'41.7"W, 19 iii 2002 (fl), Daly et al. 11470 (MICH); Feijó, Porto Marque, village of Paraíso, E side of Rio Purus, $08^{\circ} 51^{\prime} \mathrm{S}, 71^{\circ} 14^{\prime} \mathrm{W}, 13$ iv 2002 (fr), Delprete et al. 8299 (NY); Cruzero do Sul, vicinity of Serra da Moa, 24 iv 1971 (fr), Prance et al. 12387 (NY); Mpio. Marechal Traumaturgo, Rio Alto Juruá, Reserva Extrativista de Alto Juruá, N de São João do Breu, margem esquerda, Seringal Damião, colocação Belfort, $09^{\circ} 11^{\prime} \mathrm{S}, 72^{\circ} 41^{\prime} \mathrm{W}, 10$ iv 1993 (fr), Silveira 521 (MICH). Colombia. Amazonas: Peña Roja, 18 x 1993 (fl), Leal 6 (COAH, MICH); vicinity of Leticia, Río Amazonas, ix 1946 (fl), Schultes 8361a (GH); Mpio. Puerto Santander, Río Caquetá, entre comunidades indígenas de Villazul y Peña Roja, 11 xi 1995 (fl), van Dulmen 352 (COAH, COL). Peru. Amazonas: Río Santiago, 2 km astás de Caterpiza, 18 ix 1979 (fl), 
Huashikat 993 (MO); Prov. Condorcanqui, Dtto. El Cenepa, Comunidad Aguarana Pagki-

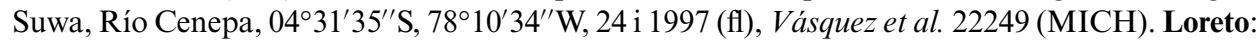
Prov. Alto Amazonas, Andoas, Río Pastaza near Ecuador border, $02^{\circ} 48^{\prime} \mathrm{S}, 76^{\circ} 28^{\prime} \mathrm{W}, 15$ viii 1980 (fl, y fr), Gentry et al. 29818 (MO); Prov. Alto Amazonas, Andoas, campamento petrolero, Río Pastaza, N de Iquitos, $02^{\circ} 55^{\prime} \mathrm{S}, 7^{\circ} 25^{\prime} \mathrm{W}, 21$ xi 1980 (fr), Vásquez \& Jaramillo 866 (MO); Prov. Alto Amazonas, Andoas (margen izquierda del Río Pastaza) Campamento OXI, $02^{\circ} 55^{\prime} \mathrm{S}$, $76^{\circ} 25^{\prime}$ W, 5 vi 1981 (fl), Vásquez \& Jaramillo 1917 (MO). Ucayali: Prov. Purús, Dtto. Purús, Río la Novia, margen derecha del caserio natia San José, $10^{\circ} 12^{\prime} \mathrm{S}, 70^{\circ} 57^{\prime} \mathrm{W}, 26$ ii 2002 (fl), Schunke V. \& Graham S14903 (MICH).

Tetrapterys amazonica is listed as "Tetrapterys sp. nov. 1" in the Catálogo de Plantas y Líquenes de Colombia (Anderson \& Anderson, 2016). The dense golden-sericeous vesture of the inflorescence immediately separates Tetrapterys amazonica from all other Amazonian species of Tetrapterys with connate stipules, glabrous laminas and 4flowered umbels. Another unusual character is the adaxial vesture of the stipules. The widespread Tetrapterys crispa A.Juss. and T. discolor (G.Mey.) DC. share the glabrous laminas, but in both the stipules are abaxially glabrous, and the inflorescences bear shorter white hairs. The large basal glands on the abaxial surface of laminas also set Tetrapterys amazonica apart from T. crispa and T. discolor. In addition, the samara of Tetrapterys crispa lacks winglets and/or outgrowths between the lateral and dorsal wing.

\section{Tetrapterys callejasii W.R.Anderson, sp. nov.}

Tetrapterys callejasii differs from T. discolor (G.Mey.) DC. in its elongate goldensericeous inflorescence, smaller stipules, bracteoles inserted below the apex of the peduncle, and presence of a single winglet on the nut of the samara between the lateral and dorsal wings. - Type. Colombia, Antioquia: Mpio. San Luis, cañón del

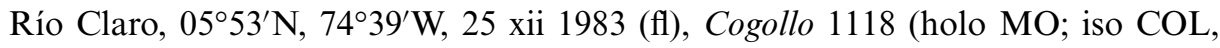
HUA). Fig. 5.

Vine or shrub to $10 \mathrm{~m}$. Stems densely sericeous when young, soon glabrous. Laminas of larger leaves $8-16.5 \times 3-6 \mathrm{~cm}$, narrowly to broadly elliptical, apex acuminate, base briefly truncate or acute, adaxially and abaxially glabrous, margin thickened, with scattered glands on the abaxial surface, glands $0.3-0.5 \mathrm{~mm}$ diam.; petiole $2-7 \mathrm{~mm}$ long, initially sericeous but soon glabrous, eglandular; stipules connate, $1-1.3 \times 0.5-0.8 \mathrm{~mm}$, narrowly triangular, adaxially glabrous, abaxially sericeous. Inflorescence terminating in umbels of 4 flowers borne on a long continuous main axis, singly or in small aggregates, golden-sericeous; inflorescence bracts $3.5-8 \mathrm{~mm}$ long and wide, orbicular or suborbicular or broadly ovate, with $0-1(-2)$ glands $(0.3-) 0.5-0.6 \mathrm{~mm}$ diam. on each side of costa, deciduous in fruit; floriferous bracts $1-1.3 \mathrm{~mm}$ long, triangular; peduncle 3-6 mm long, densely sericeous; bracteoles $0.7-1 \mathrm{~mm}$ long, broadly triangular to ovate, inserted at middle of peduncle to c. $0.05 \mathrm{~mm}$ below apex; pedicel $2.5-4.5 \mathrm{~mm}$ long. Sepals $0.5-1.2 \mathrm{~mm}$ long and wide beyond glands, apex rounded and ciliate, adaxially glabrous, abaxially proximal $1 / 3$ or less sericeous or all glabrous, abundantly pubescent between glands, apex rounded and ciliate, anterior sepal eglandular, the lateral 4 


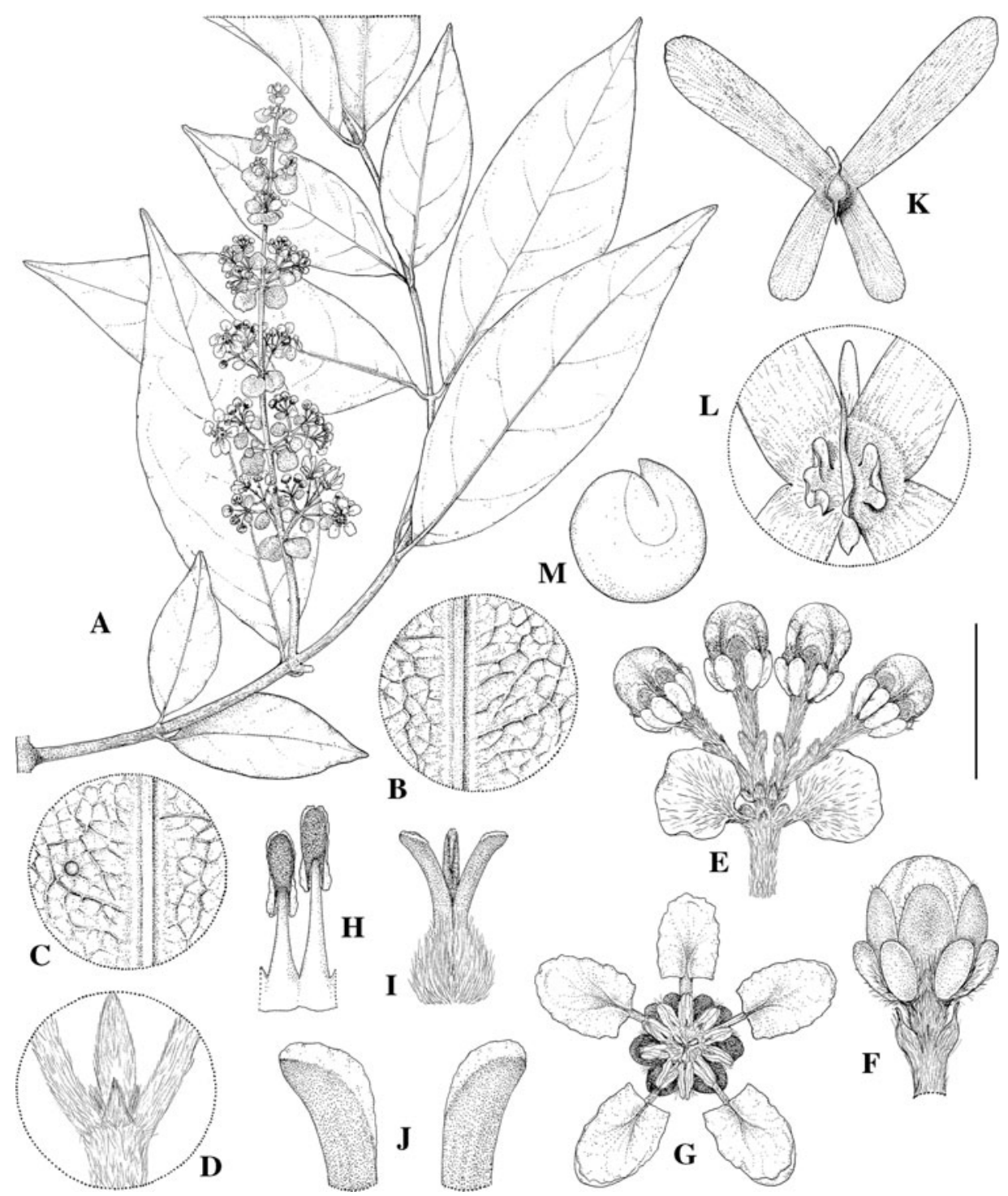

FIG. 5. Tetrapterys callejasii W.R.Anderson. A, Flowering branch; B, adaxial surface of lamina enlarged; C, abaxial surface of lamina enlarged; D, node with connate pair of interpetiolar stipules; E, umbel of flower buds; F, flower bud; G, flower, posterior petal uppermost; H, two stamens, abaxial view, the one with longer filament opposite a sepal; I, gynoecium, anterior style in centre; J, distal portion of anterior style (left) and posterior style (right); K, samara, adaxial view; L, enlargement of nut of samara, abaxial view; M, embryo. Scale bars: A, $4 \mathrm{~cm}$; B-D, $4 \mathrm{~mm}$; E, $8 \mathrm{~mm}$; F, $2.7 \mathrm{~mm}$; G, $5.7 \mathrm{~mm}$; H and I, $2.7 \mathrm{~mm}$; J, $1 \mathrm{~mm}$; K, $2 \mathrm{~cm}$; L, $1 \mathrm{~cm}$; M, $4 \mathrm{~mm}$. A-J based on Cogollo \& Brand 367, MO; and K-M on Cárdenas et al. 2555, MICH. 
biglandular, glands $2.5-3 \mathrm{~mm}$ long. Petals yellow, lateral petals with the claw c. $2 \times$ c. $0.3 \mathrm{~mm}$, limb of anterior-lateral petals $4.5-5 \times 3-4 \mathrm{~mm}$, limb of posterior-lateral petals $5-5.5 \times$ c. $4 \mathrm{~mm}$, claw of posterior petal c. $2.5 \times$ c. $0.5 \mathrm{~mm}$, limb c. $4.5 \times$ c. $3 \mathrm{~mm}$, all limbs oblong, slightly cucullate, base truncate or briefly sagittate, margin subentire or minutely erose. Filaments $1.5-2.5 \mathrm{~mm}$ long, glabrous, connate at base; anthers 1.2 $1.5 \mathrm{~mm}$ long, subequal, glabrous. Ovary c. $1.5 \mathrm{~mm}$ long, hirsute, styles glabrous, anterior style 1.5-2 mm long, posterior styles $1.5-1.7 \mathrm{~mm}$ long, stigmas terminal and decurrent at internal angle. Samara with the wings sparsely sericeous; lateral wings distinct or united for c. $0.05 \mathrm{~mm}$ at base, apex rounded, the upper $2-3 \times 0.8-1 \mathrm{~cm}$, the lower $0.9-1.6 \times 0.4-0.6 \mathrm{~cm}$; dorsal wing $1.5-4.5 \mathrm{~mm}$ high, margin slightly undulate; nut 5-5.5 mm diam., sparsely sericeous, between dorsal and lateral wings with a winglet to $4 \mathrm{~mm}$ high; areole $3-3.5 \times 2-2.5 \mathrm{~mm}$; embryo spherical.

Distribution. Colombia (Antioquia, Chocó).

Habitat. Primary and disturbed forests; 70-800(-1500) $\mathrm{m}$.

Etymology. The specific epithet honours the Colombian botanist Ricardo Callejas Posada (b. 1954) in recognition of his contributions to the study and conservation of the Colombian flora.

Additional specimens examined. Colombia. Antioquia: Mpio. Anorí, Corregim. Providencia, 1991 (fl/fr), Albert de Escobar 49 (HUA); Mpio. Mutatá, colinas al E de la vereda Caucheras, 15 xii 1982 (old infl), Bernal R. 495 (COL); Mpio. Puerto Berrío, vereda Alicante, finca Penjamo, San Juan de Bedout-La Cabaña, 06 39'N, 74³2'W, 1 iii 1990 (fr), Callejas et al. 9242 (HUA, MICH); Mpio. Tarazá, Corregim. El Doce, 210 km NE de Medellín, Km 4 en la vía al caserío de Barroblanco, 1-2 km NW de la Finca Las Mercedes, Quebrada La Quebradona, $07^{\circ} 30^{\prime} 00^{\prime \prime} \mathrm{N}$, $75^{\circ} 20^{\prime} 00^{\prime \prime} \mathrm{W}, 1998$ (fl), Callejas 11045 (HUA); Mpio. San Luis, Corregim. el Prodigio, vereda "Las Confusas," 0603'N, 7447’W, 7 iii 1990 (fr), Cardenas L. et al. 2552 (JAUM), 2555 (JAUM, MICH); Mpio. Puerto Berrío, carretera Cisneros-Puerto Berrío, sitio La Carlota, Quebrada El Vapor, $06^{\circ} 37^{\prime} \mathrm{N}, 7^{\circ} 27^{\prime} \mathrm{W}, 4$ ii 2001 (fr), Cardona et al. 1057 (HUA, MO); Mpio. San Luis, autopista Medellín-Bogotá, 2 km de Río Claro hacia Río Samaná, i 1983 (fl/fr), Cogollo \& Brand 367 (JAUM, MO); Mpio. Zaragoza, carretera a Zaragoza entre Carrallao y Angostura, 13 i 1989 (fl), Fonnegra G. \& Roldán 2576 (HUA, MICH, MO); Mpio. San Luis, quebrada "La Cristalina," $06^{\circ} \mathrm{N}, 7^{\circ} 45^{\prime} \mathrm{W}, 22$ i 1987 (fl), Ramírez \& Cárdenas L. 363 (COL, HUA, JAUM, MO), 24 i 1987 (fr) 430 (COL HUA, JAUM, MO), 21 ii 1987 (fr), 572 (COL, HUA, JAUM, MO), 23 ii 1987 (sterile), 622 (MO), 25 v 1987 (fl), 1019 (COL, HUA, JAUM, MO); Mpio. Anorí, Corregim. Providencia, Buenos Aires, 21 x 1972 (fl), Soejarto 3417 (MICH); Anorí, between Providencia and Alhibe, 20-25 ii 1976 (fr), Soejarto et al. 4426 (HUA, MICH). Cesar: valle del Río Cesar (parte occidental), selva marginal del Caño Sagarriga, al W de Los Venados, $10^{\circ} 00^{\prime} 00^{\prime \prime} \mathrm{N}, 73^{\circ} 45^{\prime} 00^{\prime \prime} \mathrm{W}, 13$ i 1983 (ffl/fr), Hernández et al. 671 (COL). Chocó: Mpio. Riosucio, zona de Urabá, Cerro del Cuchillo, 17 i 1988 (fl/fr), Cardenas 1072 (JAUM, MO). Santander: Mpio. Suaita, vereda La Meseta, camino entre La Meseta y la cascada Los Caballeros, $06^{\circ} 10^{\prime} \mathrm{N}$, $73^{\circ} 27^{\prime} \mathrm{W}, 27$ iii 2004 (fl), Betancur 10639 (COL); Mpio. El Playón, vereda La Negreña, $07^{\circ} 29^{\prime} \mathrm{N}$, $73^{\circ} 12^{\prime} \mathrm{W}, 16$ ix 2003, Galván 1304 (HUA).

Tetrapterys callejasii is listed as "Tetrapterys sp. nov. 3" in the Catálogo de Plantas y Liquenes de Colombia (Anderson \& Anderson, 2016). It is distinctive in its elongate inflorescence bearing the 4-flowered umbels, singly and grouped in cymes, and in its 
samara with a single winglet placed on the nut between the lateral and dorsal wing. In the treatment of Tetrapterys for Colombia by Cuatrecasas (1958) T. callejasii keys to T. discolor (G.Mey.) DC., but it is easily separated from that species with the following couplet.

a. Inflorescence an elongate continuous axis, golden-sericeous; bracteoles inserted at middle of peduncle to c. $0.05 \mathrm{~mm}$ below apex; stipules $1-1.3 \times 0.5-0.8 \mathrm{~mm}$; nut of samara bearing one winglet between lateral and dorsal wings T. callejasii

b. Inflorescence cymose-paniculate, white-sericeous; bracteoles inserted at apex of peduncle; stipules 1.5-2.5(-3.5) × 1-1.5(-2.5) mm; nut of samara bearing several narrow winglets and/or aculeate outgrowths between lateral and dorsal wings T. discolor

\section{Tetrapterys steyermarkii W.R.Anderson, sp. nov.}

Tetrapterys steyermarkii differs from T. discolor (G.Mey.) DC. and T. seemannii Triana \& Planch. in its tree or shrub habit and its shorter petioles, from $T$. discolor also in its glabrous samaras, and from $T$. seemannii also in having the lateral wings of the samara only very slightly united. - Type: Venezuela, Falcón: 26-30 km al S de Coro, 25 i 1966 (fr), Steyermark \& Braun 94706 (holo NY; iso US, VEN). Fig. 6.

Tree to $6 \mathrm{~m}$ or shrub; stems thinly sericeous when young, soon glabrous. Laminas of larger leaves $7-15 \times 3-8.5 \mathrm{~cm}$, elliptical to broadly so, apex acuminate (or briefly so in smaller broad laminas), base acute or briefly truncate, adaxially and abaxially initially sericeous but very soon glabrous, with (2-)3-5(-6) glands $0.3-0.5 \mathrm{~mm}$ diam. borne on each side of costa on the abaxial surface; petiole 3-6(-8) $\mathrm{mm}$ long, glabrous, eglandular; stipules connate, (1.5-)2-4 × 1-1.7 mm, triangular to ovate, adaxially glabrous, abaxially sericeous or only proximally so to glabrate, at the distalmost inflorescence nodes shorter and sometimes apically notched. Inflorescence terminating in umbels of 4 flowers, paniculate, thinly sericeous to glabrescent; inflorescence bracts $0.4-2.5(-3.5) \times 0.3-2(-2.3) \mathrm{cm}$, elliptical to ovate, usually with 1 or 2 glands borne on each side of costa on abaxial surface or at base, deciduous in fruit; floriferous bracts 1-2.2 mm long, narrowly triangular; peduncle (2.3-)3-6 mm long, densely sericeous; bracteoles $0.9-1.1(-1.5) \mathrm{mm}$ long, ovate, inserted at apex of peduncle; pedicel 3.5$6 \mathrm{~mm}$ long, sericeous or sparsely so. Sepals $1.3-1.8 \mathrm{~mm}$ long beyond glands, apex rounded and ciliate, adaxially and abaxially glabrous, the anterior eglandular, the lateral 4 biglandular, glands $2-2.5 \mathrm{~mm}$ long. Petals yellow, carinate, lateral petals with the claw $1.5 \times$ c. $0.4 \mathrm{~mm}$, limb 5-5.7 $\times 3.3-4 \mathrm{~mm}$, narrowly obovate, base briefly sagittate, margin subentire or minutely erose, claw of posterior petal 1.5-2 $\times 0.4$ $0.5 \mathrm{~mm}$, limb 5-5.7 $\times 3-4 \mathrm{~mm}$, oblong, base truncate or sometimes briefly sagittate. Filaments $1.5-2.5 \mathrm{~mm}$ long, glabrous, connate at base; anthers $0.9-1.3 \mathrm{~mm}$ long, subequal, glabrous. Ovary 1-1.2 mm long, hirsute, styles glabrous, anterior style 1.7-2.5 $\mathrm{mm}$ long, posterior styles $1.5-2.3 \mathrm{~mm}$ long, stigmas terminal and decurrent at internal angle. Samara glabrous; upper lateral wings distinct or united for up to $2.5 \mathrm{~mm}$ at base, apex rounded, the upper $1.4-2 \times 0.6-0.7 \mathrm{~cm}$, the lower $0.6-1 \times \mathrm{c} .0 .6 \mathrm{~cm}$; dorsal 


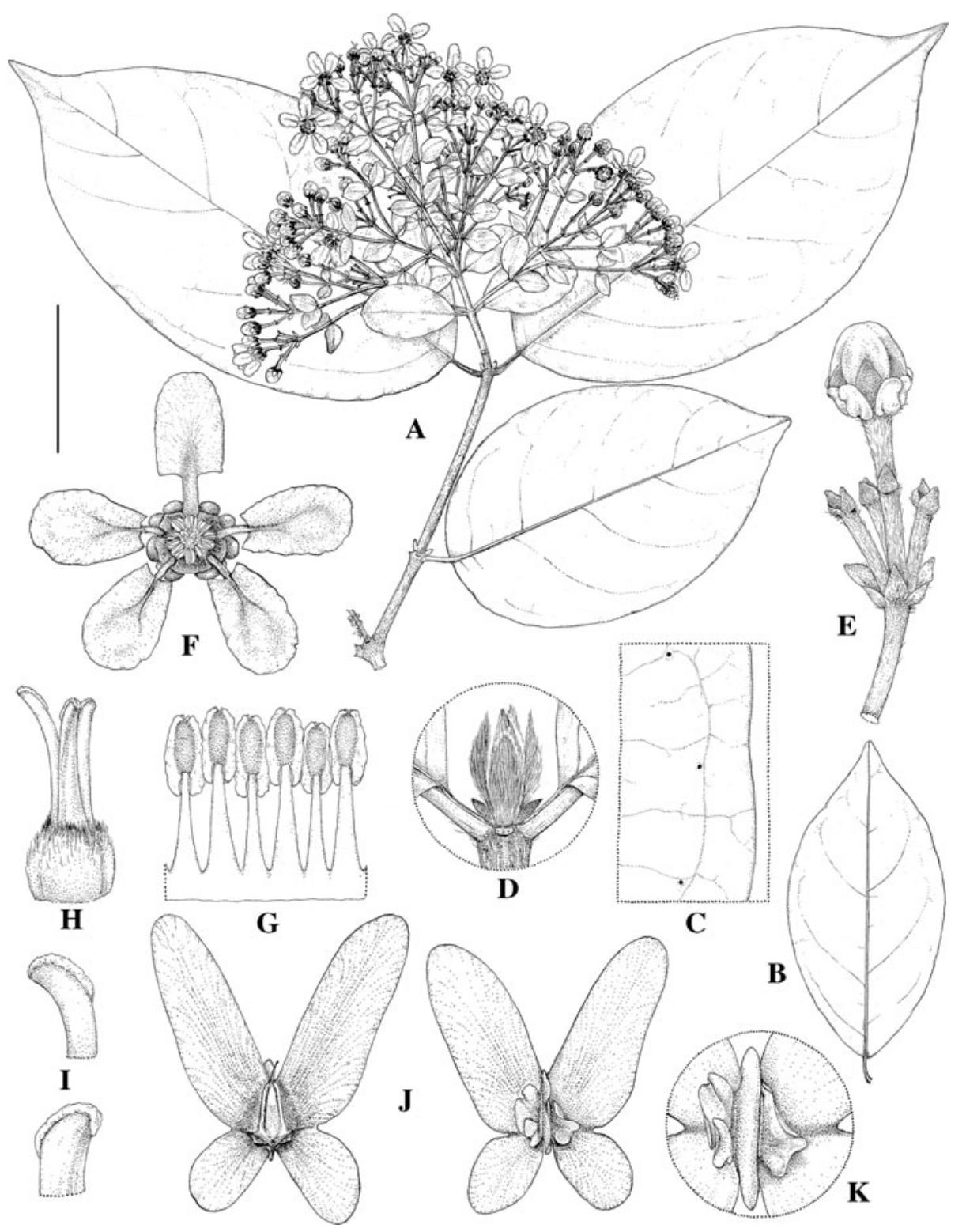

FIG. 6. Tetrapterys steyermarkii W.R.Anderson. A, Flowering branch; B, small leaf, abaxial view; C, lamina, abaxial view, showing tiny inframarginal glands; $D$, apical node, showing scar left by tiny stipule pair; E, umbel of four flower buds with three buds removed above bracteoles; F, flower, posterior petal uppermost; G, partial androecium laid out, abaxial view, the stamen third from left opposite posterior petal; $\mathrm{H}$, gynoecium, anterior style at left; I, distal portions of styles, anterior style (above) and posterior style (below); J, samaras, adaxial view (left) and abaxial view (right); K, enlargement of nut of samara, abaxial view. Scale bars: A and B, $4 \mathrm{~cm}$; C-F, $8 \mathrm{~mm}$; G and H, $2.7 \mathrm{~mm}$; I, $1.3 \mathrm{~mm} ; \mathrm{J}, 1.3 \mathrm{~cm}$; K, 8 mm. A-I based on Bunting 5396, MICH; and $\mathrm{J}$ and $\mathrm{K}$ on Steyermark \& Braun 94706, US. 
wing 4.5-6 mm high, subentire; nut 5-5.5 $\mathrm{mm}$ diam., between dorsal and lateral wings smooth and with winglets; areole $4.5-5 \times$ c. $2.5 \mathrm{~mm}$; embryo spherical.

Distribution. Colombia (Cesar, La Guajira, Magdalena) and Venezuela (Falcón, Lara, Zulia).

Habitat. Dry tropical forests and desert chaparral; sea level to $1200 \mathrm{~m}$.

Etymology. The species is named for Julian Alfred Steyermark (1909-1988), indefatigable taxonomist, floristician and collector.

Additional specimens examined. Colombia. Cesar: hoya del Río Cesar (hoya del Río Azucarbuena, región del Callao, 29 xi 1959 (fr), Cuatrecasas \& Romero Castaneda 24965 (COL); Valledupar, ix 1938 (fl), Haught 2337 (A, COL). Guajira: Mpio. Macaio, 4-5 km N of Loma Chimbolo, on the Intercor railroad corridor, 19 v 1981, Arboleda et al. 650 (HUA, MEDEL); Proyecto El Cerrejón, entre Roche y Tabaco, sitio 11, 18 xi 1980, Bunch P. s.n. (HUA); highway near Villanueva, 11 ix 1944 (fl/fr), Haught 4354 (COL, GH); Mpio. Fonseca, Corregim. Distracción, sitio Las Casitas-El Socorro, $10^{\circ} 09^{\prime} \mathrm{N}, 72^{\circ} 59^{\prime} \mathrm{W}, 31$ viii 1990, Marulanda \& Betancur (sterile) 2112 (HUA), (fr) 2140 (COL, HUA, MICH, MO). Magdalena: Mpio. Santa Marta, vereda Neguanje, $11^{\circ} 15^{\prime} 22^{\prime \prime} \mathrm{N}, 74^{\circ} 06^{\prime} 41^{\prime \prime} \mathrm{W}, 10$ xii 2008, Botero B. 1124 (MEDEL); Mpio. Santa Marta, Parque Nal. Tayrona, Bahia de Chengue, 29 xii 1974 (in bud), López 844 (COL); Mpio. Santa Marta, Parque Nacional de Tayrona, Ensenada de Neguanje, 9 ix 1976 (fl), Lozano \& Schnetter 2775 (COL), 2777 (F), 14 ix 1976 (fr), 2821 (COL), 23 ix 1976 (fl), 2960 (COL); Parque Nacional Natural Tayrona, Gairaca, alrededores de la quebrada, ix 1979 (fr), Moreno B. 84 (COL). Venezuela. Falcón: Cerro Socopo, 30 vi 1979 (fr), Liesner et al. 8456 (MICH); cerca de Tiguaje, 22 x 1963 (fr), Madriz 20 (MY); Dtto. Mauroa, Caño Antiguo, 5 x 1977 (fr), Ruiz Z. y Equipo de Ecología 2125 (MICH); Dtto. Mauroa, La Antigua, 11 x 1977 (fr), Ruiz Z. y Equipo de Ecología 2249 (MICH); Dtto. Buchivacoa, Cerros de Flor Bonita, 3 xi 1977 (fr), Ruiz Z. y Equipo de Ecología 2392 (MICH). Lara: Dtto. Iribarren, Tierra Brava, carretera Barquisimeto-Churuguara, 8 xi 1979 (fl), Marcano-Berti et al. 366-979 (MICH, NY), 8 xi 1979 (fr), 373-979 (MICH); Duaca, 1893-94 (fl), Mocquerys s.n. (MICH, P); between Carora and Trentino, 16 i 1928 (fr), Pittier 12614 (G, NY, US, VEN); camino Barquisimeto-Churuguara, $10^{\circ} 05^{\prime} \mathrm{N}, 69^{\circ} 28^{\prime} \mathrm{W}, 22$ i 1982 (fr), Rutkis 433 (MICH, VEN); Dtto. Palavecino, entre Terepaima y Cabudare, 5-10 viii 1970 (fl), Steyermark et al. 103433 (MICH, NY, VEN); Dtto. Iribarren, Mpio. Concepción, zona media de Loma de Léon, 20 ix 1950 (fl/fr), Tamayo 3745 (NY, VEN); Dtto. Iribarren, Cerro de Titicare, carretera a Río Claro, 22 ix 1950 (fl), Tamayo 3768 (NY, VEN); Barquisimeto, Loma de León, 13 vii 1954 (fl), Vivas 43 (VEN). Zulia: Dtto. Miranda, carretera Maracaibo-Altagracia, en el Km 4 al N del desvío a la carretera Maracaibo-Coro, 8 ix 1977 (fl), Bunting 5396 (VEN).

Tetrapterys steyermarkii is listed as "Tetrapterys sp. nov. 5" in the Catálogo de Plantas $y$ Líquenes de Colombia (Anderson \& Anderson, 2016). It is a small tree or shrub with thinly sericeous stems and inflorescences, which are soon glabrescent to glabrous, and leaves with very short petioles. The fruits are glabrescent as soon as the wings begin to enlarge; the mature samaras are glabrous. Most collections of Tetrapterys steyermarkii were left unnamed, but in Colombia some had been included in $T$. discolor (e.g. Cuatrecasas, 1958), and in Venezuela some had been misdetermined as T. anisoptera A.Juss., known only from Bahia, Brazil; both species are vines with the young inflorescences and fruits bearing abundant hairs. Tetrapterys steyermarkii 
shares glabrous samaras with T. seemannii Triana \& Planch. of Costa Rica, Panama, Colombia and Venezuela; they differ as follows.

a. Shrub or small tree; petioles 3-6(-8) mm long; samara with lateral wings distinct or only slightly connate, the upper ones about $2-3$ times as long as the lower, with 1 to several broad outgrowths between lateral and dorsal wings, the dorsal wing free from lateral wings at base and apex or only slightly fused with them T. steyermarkii

b. Woody vine, occasionally described as shrubby with elongated branches; petioles (6-)8-12 mm long; samara with lateral wings broadly confluent, the upper ones 3-5 times as long as the lower or longer, without outgrowths between lateral and dorsal wings or very rarely with 1 very small narrow one T. seemannii

\section{ACKNOWLEDGEMENTS}

The species here described are part of studies of Malpighiaceae that William R. Anderson did not live to complete. We are both indebted to the many Colombian botanists who assisted us during our visit to Colombian herbaria in 2009, for their unfailing hospitality and generosity. Karin Douthit drew the handsome illustrations. David Barrington and Eunice Froeliger kindly sent an image of the isotype of Tetrapterys rzedowskii at VT. I thank Thomas F. Daniel and an anonymous reviewer for their helpful comments. The curators of the following herbaria provided access to their collections and extended many courtesies during visits: A, BM, COAH, COL, DS, ENCB, F, G, GH, HUA, IEB, JAUM, MEDEL, MEXU, MICH, MO, MY, NY, US, VEN and WIS. This study was supported in part by grants from the American Philosophical Society and the National Science Foundation to the University of Michigan (DEB-0543909).

\section{REFERENCES}

Anderson, W. R. \& Anderson, C. (2016). Malpighiaceae. In: Bernal R., Gradstein S. R. \& Celis M. (eds) Catálogo de Plantas y Líquenes de Colombia, 2: 1512-1535. Bogotá: National University of Colombia. Online. Available: http://catalogoplantasdecolombia.unal.edu.co

Cuatrecasas, J. (1958). Prima Flora Colombiana. 2. Malpighiaceae. Webbia 13: 343-664.

Davis, C. C. \& Anderson, W. R. (2010). A complete generic phylogeny of Malpighiaceae inferred from nucleotide sequence data and morphology. Amer. J. Bot. 97(12): 2031-2048.

Niedenzu, F. (1928). Tetrapterys. In: Engler A. (ed.) Das Pflanzenreich: Regni Vegetabilis Conspectus, vol. IV. 141, pars 1 (Heft 91), pp. 155-224. Leipzig: Wilhelm Engelmann. 